\title{
NEW RECORDS AND MORPHOLOGICAL ASSESSMENTS OF LONG- NOSED FRUIT BATS (CHIROPTERA: PTEROPODIDAE: Macroglossus spp.) FROM VIETNAM
}

\author{
Hoang Trung Thanh ${ }^{1,2, *}$, Nguyen Truong Son ${ }^{3,4}$, Vu Thuy Duong ${ }^{1}$, \\ Nguyen Thanh Luong ${ }^{3}$, Dao Nhan Loi ${ }^{5}$, Vu Dinh Thong ${ }^{3,4}$ \\ ${ }^{1}$ Faculty of Biology, VNU University of Science, Vietnam National University, Ha Noi \\ ${ }^{2}$ Centre for Life Science Research, VNU University of Science, \\ Vietnam National University, Ha Noi \\ ${ }^{3}$ Institute of Ecology and Biological Resources, VAST, Ha Noi, Vietnam \\ ${ }^{4}$ Graduate University of Science and Technology, VAST, Ha Noi, Vietnam \\ ${ }^{5}$ Faculty of Agriculture and Forestry, Tay Bac University, Son La, Vietnam
}

Received 20 October 2019, accepted 18 December 2019

\begin{abstract}
Long-nosed fruit bat is a common name of the genus Macroglossus which comprises two species: Dagger-toothed long-nosed fruit bat (M. minimus) and Greater long-nosed fruit bat $(M$. sobrinus). These two species were rarely recorded from Vietnam or neighboring countries. Within Vietnam, M. minimus has been recorded only from two localities in southern Vietnam while M. sobrinus was known from all northern, central and southern regions of the country. Morphological features of these species in Vietnam were poorly documented in previous publications. With results from a rapid examination of all specimens and recently captured individuals, we here confirm that $M$. sobrinus is distinctively larger than $M$. minimus in all external and craniodental measurements. Two species are also distinguishable by their nostril shapes and mandible symphyses. This paper provides new distributional records of both $M$. sobrinus and M. minimus from Vietnam with remarks on their ecology and habitats.
\end{abstract}

Keywords: Long-nosed fruit bats, taxonomy, distribution, Vietnam.

Citation: Hoang Trung Thanh, Nguyen Truong Son, Vu Thuy Duong, Nguyen Thanh Luong, Dao Nhan Loi, Vu Dinh Thong, 2019. New records and a morphological assessment of long-nosed fruit bats (Chiroptera: Pteropodidae: Macroglossus spp.) from Vietnam. Academia Journal of Biology, 41(4): 117-124. https://doi.org/10.15625/26159023/v41n4.14695.

*Corresponding author email: thanhht_ksh@vnu.edu.vn

C2019 Vietnam Academy of Science and Technology (VAST) 
Hoang Trung Thanh et al.

\section{INTRODUCTION}

Long-nosed (also named as long-tongued) fruit bats are regarded to species of the genus Macroglossus belonging to the family Pteropodidae (Mickleburgh et al. 1992). The genus Macroglossus was first recognized by Cuvier (1824). To date, it comprises only two species: $M$. sobrinus and $M$. minimus. According to Corbet \& Hill (1992) and Simmons (2005), M. sobrinus includes two subspecies $(M . \quad s$. sobrinus and $M . \quad s$. fraternus) while $M$. minimus includes four ones (M. m. lagochilus, M. m. booensis, M. m. minimus and $M$. $m$. nanus). Of these, the earlier species distributes in northeast India, Burma, central and south Thailand, south Laos, Vietnam, Sumatra, Java, Bali, and Sipora, Siberut, and Mentawai Isls (Indonesia); the later species has been recorded from Thailand to Philippines, Indonesia, Papua New Guinea, Solomon Isls, and North Australia (Simmons 2005).

Morice (1875) included the first record of Long-nosed fruit bat from Ho Chi Minh City (the former name "Sai Gon"), southern Vietnam with identification of specimens of M. minimus as Pteropus minima. Van Peenen et al. (1969) recorded this species in Lam Dong, Con Dao islands and "North Vietnam". Over the past decades, records of both species of Long-nosed fruit bats (M. sobrinus and $M$. minimus) from Vietnam were included in several publications (Huynh et al. 1994; Hendrichsen et al. 2001; Thong 2002; Khoi \& Thong 2005; Son \& Csorba 2007; Can et al. 2008; Kruskop 2013). However, some publications did not refer to any specimen and some records of $M$. minimus were likely resulted from misidentifications of $M$. sobrinus (Hendrichsen et al. 2001; Kruskop 2013).

This paper represents detailed
morphological measurements and
characteristics for identification of Long-
nosed fruit bats in Vietnam. Information on
ecology, habitats and their distribution range
in the country is also given.

\section{MATERIALS AND METHODS}

\section{Materials}

Thirty three individuals of Long-nosed fruit bats in Vietnam were collected over the field surveys between 2000 and 2019. Of those, 29 individuals belong to $M$. sobrinus and the remainders belong to M. minimus. All specimens are preserved in alcohol and almost entire skull of each animal are extracted.

\section{Capture method}

All bats were captured using mist nets of various sizes $(3.0 \mathrm{~m} \times 4.0 \mathrm{~m} ; 3.0 \mathrm{~m} \times 9.0 \mathrm{~m}$; $3.0 \mathrm{~m} \times 12.0 \mathrm{~m}$ ) following Francis (2008), Kunz \& Parsons (2009). Nets were set up across forest trails, across the orchard, and narrow streams under forest canopy.

\section{Morphological measurements}

External morphological measurements including FA (forearm length), E (ear height), HF (hind foot length), TIB (tibia length), $3^{\text {rd }}$ $\mathrm{Mc}, 4^{\text {th }} \mathrm{Mc}$ and $5^{\text {th }} \mathrm{Mc}$ (third, fourth and fifth finger metacarpal length) were taken in the field using a digital callipers with an accuracy of $0.1 \mathrm{~mm}$. These measurements were illustrated in Bates \& Harrison (1997). Craniodental measurements including GTL (greatest skull length), CBL (condylo-basal length), CCL (condylo-canine length), $\mathrm{ZW}$ (zygomatic width), PL (palatal length), RL (rostrum length), OD (orbital diameter), IOW (interorbital width), C1-C1 (anterior palatal width), CM2 (upper tooth row), CM3 (lower tooth row), ML (mandible length from condyle), MSL (mandible symphysis length). These measurements were modified from Andersen (1912), Chasen \& Kloss (1927), Bates \& Harrison (1997), Suyanto et al. (2004), Rahman et al. (2010).

Bats were identified following Andersen (1912), Corbet \& Hill (1992), Bates \& Harrison (1997), Francis (2008), Kruskop (2013). 


\section{RESULTS AND DISCUSSION}

\section{Morphological assessment}

\section{Greater long-nosed fruit bat Macroglossus sobrinus}

All examined specimens of Greater longnosed fruit bats in this study exhibit the diagnoses of M. sobrinus described in previous publications (Andersen 1911, 1912; Bates \& Harrison 1997; Lekagul \& McNeely 1977; Hill 1983). This is a small fruit bat species with a forearm length of $49.7 \mathrm{~mm}$ (47.7-52.2), greatest skull length of $31 \mathrm{~mm}$ (29.9-32.3) (Table 1). Measurements of examined specimens are rather larger than respective ones in Lekagul \& McNeely (1977), Bates \& Harrison (1997), Hill (1983), Corbet \& Hill (1992), Koopman (1994). The third, fourth and fifth metacarpals are subequal in length. The muzzle is greatly elongated and slender, conspicously curved downward; tongue is very long with filiform papillae from the middle to the tip. The nostrils are separated by a narrow groove. The tail is quite short or even absent in several individuals (Fig. 1). The ear is medium with an average height of $15.5 \mathrm{~mm}$ ). The pelage of captured individuals is very long, dense, soft and fine. The chest is lighter than the head and more brown than red. Dorsal surface is rather clay brown with paler base of each hair while ventral surface is buffy brown. The upper surfaces of the tibia, the forearm and the inner portion of the wing membrane are covered by hairs. Both dorsal and ventral surfaces of interfemoral membrane are also covered by hairs.

Table 1. External and craniodental measurements of M. sobrinus and M. minimus from Vietnam

\begin{tabular}{|l|c|c|c|c|c|c|c|c|}
\hline \multirow{2}{*}{ Parameter } & \multicolumn{4}{|c|}{ M. sobrinus } & \multicolumn{5}{c|}{ M. minimus } \\
\cline { 2 - 9 } & Mean & SD & Range & $\mathrm{n}$ & Mean & SD & Range & $\mathrm{n}$ \\
\hline FA & 49.7 & 0.26 & $47.7-52.2$ & 17 & 41.9 & - & $41.7-42$ & 2 \\
\hline E & 15.5 & 0.12 & $14.5-16.8$ & 14 & 14 & - & $13.5-14.4$ & 2 \\
\hline HF & 11.7 & 0.11 & $10.7-12.6$ & 17 & 9.8 & - & $9.7-9.9$ & 2 \\
\hline Tibia & 19.8 & 0.15 & $19-21.2$ & 17 & 15.6 & - & $15.1-16$ & 2 \\
\hline $3^{\text {rd }}$ Mc & 37.7 & 0.3 & $35.3-40.3$ & 17 & 30.6 & - & $30.1-31$ & 2 \\
\hline $4^{\text {th }}$ Mc & 37.7 & 0.25 & $35-39.7$ & 17 & 31 & - & $30.5-31.4$ & 2 \\
\hline $5^{\text {th }}$ Mc & 38.3 & 0.35 & $35.6-42$ & 17 & 30.9 & - & $30.7-31$ & 2 \\
\hline GSL & 31.02 & 0.14 & $29.89-32.25$ & 18 & 25.91 & 0.35 & $25.48-26.61$ & 3 \\
\hline CBL & 29.46 & 0.15 & $28.51-30.98$ & 18 & 24.50 & 0.11 & $24.35-24.73$ & 3 \\
\hline CCL & 27.58 & 0.14 & $26.94-29.01$ & 18 & 22.90 & 0.05 & $22.81-22.96$ & 3 \\
\hline ZW & 15.69 & 0.16 & $14.95-17.28$ & 18 & 14.07 & 0.42 & $13.53-14.9$ & 3 \\
\hline PL & 16.85 & 0.11 & $16.29-17.69$ & 18 & 13.6 & 0.15 & $13.31-13.75$ & 3 \\
\hline RL & 11.41 & 0.11 & $10.62-12.54$ & 18 & 8.70 & 0.34 & $8.2-9.34$ & 3 \\
\hline IOW & 5.08 & 0.07 & $4.67-5.58$ & 18 & 4.97 & 0.13 & $4.77-5.21$ & 3 \\
\hline OD & 6.65 & 0.05 & $6.29-7$ & 18 & 5.87 & 0.04 & $5.83-5.94$ & 3 \\
\hline C1-C1 & 5.62 & 0.04 & $5.32-5.9$ & 18 & 5.03 & 0.25 & $4.58-5.43$ & 3 \\
\hline CM2 & 10.19 & 0.09 & $9.43-10.99$ & 18 & 8.23 & 0.13 & $7.98-8.37$ & 3 \\
\hline ML & 23.16 & 0.13 & $22.54-24.17$ & 18 & 18.77 & 0.22 & $18.41-19.18$ & 3 \\
\hline MSL & 4.66 & 0.05 & $4.42-5.17$ & 18 & 4.02 & 0.06 & $3.9-4.11$ & 3 \\
\hline cm3 & 11.58 & 0.13 & $10.35-12.39$ & 18 & 9.38 & 0.12 & $9.18-9.58$ & 3 \\
\hline
\end{tabular}

The skull with an average CBL of 29.5 $\mathrm{mm}(28.5-31)$, an average CCL of $27.6 \mathrm{~mm}$ (26.9-29) (table 1). The rostrum is long and narrow. There are eight ridges on the palatal surface. The mandible is long and thin, with low processes. Symphysis keel of lower jaw is developed. In lateral view, it has a distinctly squared outline (Fig. 2). The upper tooth rows 
length of an average $10.2 \mathrm{~mm}(9.4-11)$, the lower tooth rows length of an average 11.6 $\mathrm{mm}(10.4-12.4)$ (table 1). The canines are rather short and sharp. Upper tooth rows have two molars, lower tooth rows have three to four molars.

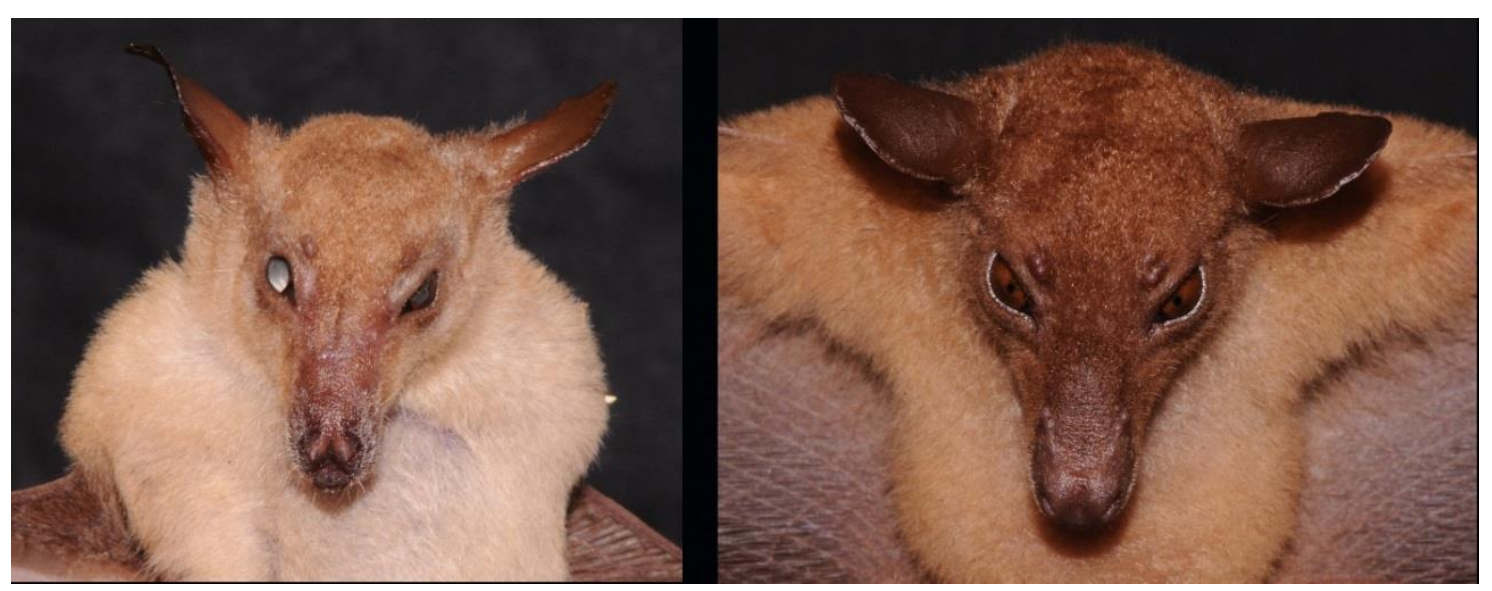

Figure. 1. Frontal view of M. minimus (left) and M. sobrinus (right) from Vietnam (not to scale)

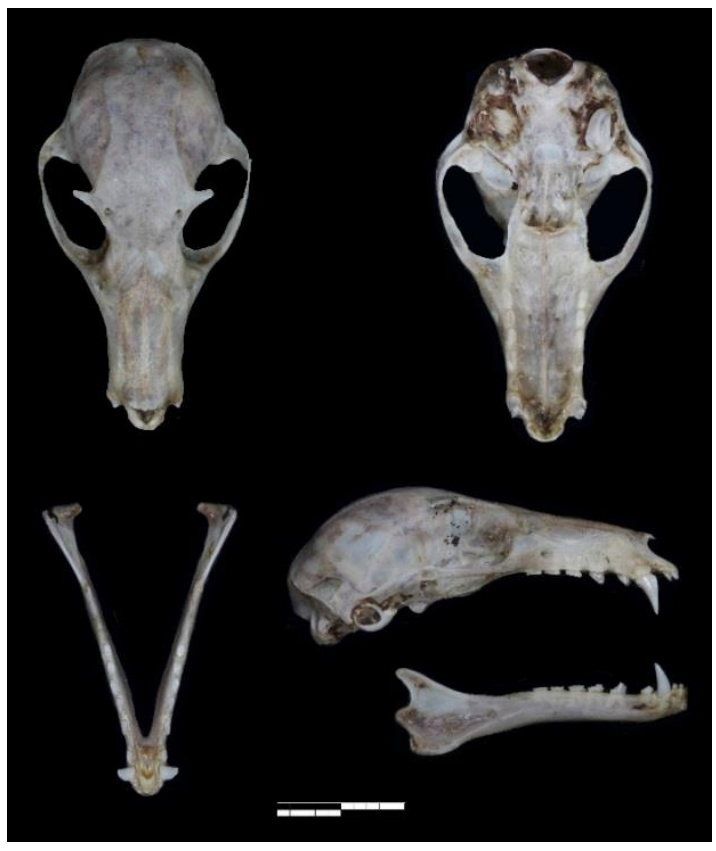

Figure. 2. Dorsal, ventral, and lateral (from top-left clockwise) views of the skull and mandible of M. sobrinus from Vietnam. Scale $=10 \mathrm{~mm}$

\section{Dagger-toothed long-nosed fruit bat Macroglossus minimus}

Four individuals of Dagger-toothed longnosed fruit bats were examined during this study. It is almost similar to that of $M$. sobrinus in morphology but distinctly smaller in size. Its forearm length of $41.9 \mathrm{~mm}$ (41.742.0), greatest skull length of $25.9 \mathrm{~mm}$ (25.526.6) (Table 1). Similar to $M$. sobrinus, lengths of the third, fourth and fifth metacarpals of $M$. minimus are subequal. The muzzle is greatly elongated and slender, but shorter than M. sobrinus; tongue is very long with filiform papillae from the middle to the tip. The nostrils are distinctly seperated by a deep internarial groove that extends to the margin of the upper lip (Fig. 1). The tail is quite short or even absent. The ears are medium (average ear height $14 \mathrm{~mm}$ ). The pelage is rather long, soft and fine. The chest is lighter than the head. Dorsal surface of almost all individuals is rather clay brown with paler hair bases. On the ventral surface, it is light brown. Hairs are present on the upper surface of the tibia, less on the forearms, above and below, and also less on the inner part of the wing membrane. The interfemoral membrane is narrow and also covered in short hairs, above and below.

The skull with an average condylobasal length of $24.5 \mathrm{~mm}$ (24.4-24.7), an average condylocanine length of $22.9 \mathrm{~mm}(22.8-23)$ (table 1). The rostrum is relatively long and 
narrow. There are eight palatal ridges on the palatal surface. The mandible is long and thin, with low processes. Symphysis keel of lower jaw is obsolescent. In lateral view, it has a slopping outline (Fig. 3). The upper tooth rows length of an average $8.2 \mathrm{~mm}(8.0$ 8.4 ), the lower tooth rows length of an average $9.4 \mathrm{~mm}$ (9.2-9.6) (Table 1). The canines are rather short and sharp. Upper tooth rows have two molars, lower tooth rows have three molars.

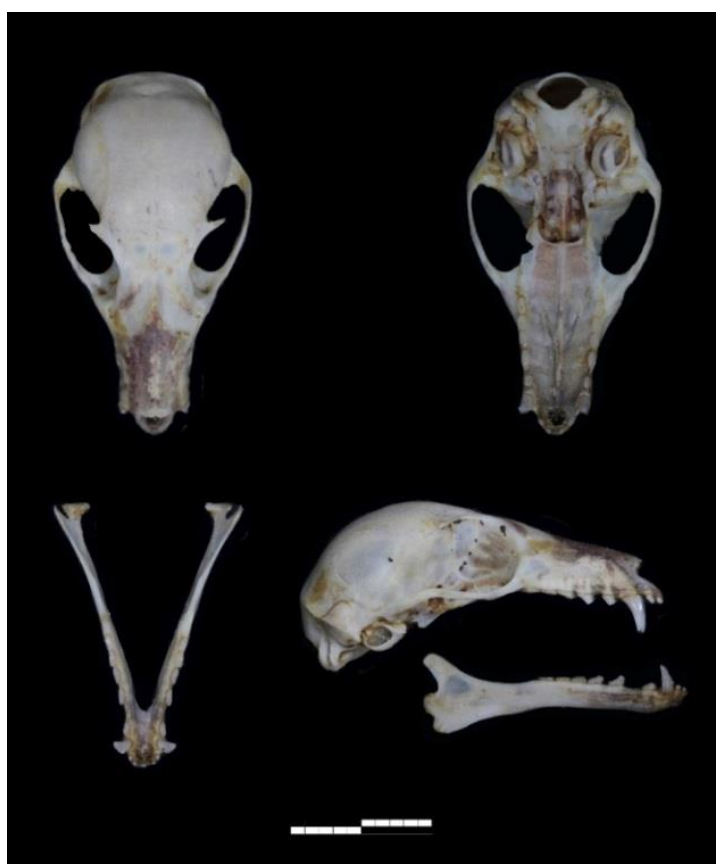

Figure. 3. Dorsal, ventral, and lateral (from top-left clockwise) views of the skull and mandible of M.minimus from Vietnam. Scale

$$
=10 \mathrm{~mm}
$$

In general, $M$. minimus and $M$. sobrinus specimens collected from Vietnam adopted diagnoses of correlative species in previous publications (Andersen 1911, 1912; Tate, 1942; Lekagul \& McNeely 1977; Hill 1983; Koopman 1994; Francis 2008). According to Corbet \& Hill (1992), Long-nosed fruit bats in Vietnam belong to subspecies $M . \quad m$. lagochilus and M. s. sobrinus. Andersen (1912) described sobrinus with tooth rows including three lower molars. Of the Vietnamese sobrinus, we found some specimens with four lower molars. This characteristics were also recognised in some individuals of Macroglossus (Jentink 1902). Based on this characteristics, Jentink (1902) described a new genus and new species, Odontonycteris and mentioned by Miller (1907). However, Andersen included these taxa in Macroglossus and commented that this is the form of dental anomaly of so frequent occurence in Macroglossus (Andersen 1912).

Almost previous records of Long-nosed fruit bats in Vietnam belong to $M$. sobrinus. Prior to this study, there are only records of Van Peenen et al. (1969) and also Kruskop (2013) in Con Dao Islands, and record of Thanh et al. (2015) in Hon Dat District, Kien Giang Province may confirm to M. minimus in Vietnam. So far, there is little information comparing diagnoses of these species in Vietnam. Of the specimens in this study, sobrinus differ from minimus in larger external size (forearm average length of 49.7 $\mathrm{mm}$ compares to $41.9 \mathrm{~mm}$ ). The nostrils in sobrinus show no suggestion of a tubular form with narrow internarial groove, differ from forward are distinctly seperated nostrils with a deep internarial groove that extend to the margin of the upper lip in minimus. The pelage rather different with buffy brown in sobrinus and clay brown in minimus. The hairs of sobrrinus longer than that of minimus.

On the skull, sobrinus has larger and longer skull than that of minimus (greatest skull length average of $31 \mathrm{~mm}$ compare to $25.9 \mathrm{~mm}$ ) with longer rostrum (length orbit to nares) $(11.4 \mathrm{~mm}$ compared to $8.7 \mathrm{~mm}$ in average) and more longer tooth rows, both upper and lower (tooth rows length of 10.2 compared to 8.2 , and 11.6 compared to 9.4 , respectively) (table 1). Of the lower jaw, sobrinus has long and keeled symphysis and has a distinctly squared outline in lateral view, whereas in minimus symphysis keel is obsolescent or absent.

\section{Distribution and Ecology}

In Vietnam, Long-nosed fruit bats were recorded from different regions. Morice recorded Pteropus minima in Sai Gon (1875) 
without detailed diagnosis. However, with systematics of Long-nosed fruit bats at that time, combined with general information on distribution of Long-nosed fruit bats in Vietnam, this record can be refer to $M$. sobrinus. According to Hendrichsen et al. (2001), measurements in Van Peenen et al. (1969) suggest that they include both minimus and sobrinus. This comment also adopts our data in this research. Records of Van Peenen et al. (1969) on long-nosed fruit bats in Long Khanh Province (today Dong Nai), Tuyen Duc Province (today Lam Dong province) and "north Vietnam" may refer to $M$. sobrinus. Corbet \& Hill (1992) recorded M. sobrinus in Vietnam but without any detailed information. Recent studies recorded $M$. sobrinus in Bac Kan, Son La, Phu Tho, Ninh Binh, Nghe An, Ha Tinh, Quang Binh, Thua Thien Hue, Quang Nam, Gia Lai, Ninh Thuan, Binh Phuoc, Dong Nai (Huynh et al. 1994; Hendrichsen et al. 2001; Thong 2002; Khoi \& Thong 2005; Son \& Csorba 2007; Can et al. 2008). Kruskop (2013) added the distribution of sobrinus in Binh Phuoc. In this study, we recorded $M$. sobrinus in Tuyen Quang, Son La, Dien Bien, Hai Duong, Nghe An, Quang Nam, Lam Dong. Records on distribution of $M$. sobrinus in Vietnam were presented in Fig. 4.

In Vietnam, $M$. sobrinus were captured in different habitats. Kruskop (2013) captured this species over a stream or near flowering bananas, in secondary plant formation. In this study, we recorded $M$. sobrinus in the secondary forest; near flowering bananas in mixed natural forest. Almost all records with very few individuals, but some places in Quang Nam we captured several individuals of $M$. sobrinus per mistnet site.

Of the distribution of $M$. minimus, as mentioned above, records of Van Peenen et al. (1969) in Con Son Island (today Con Dao) may refer to this taxon. Several records of $M$. minimus in Vietnam were likely resulted from misidentification of specimens of $M$. sobrinus (Hendrichsen et al., 2001, Kruskop, 2013). Can et al. (2008) mentioned the distribution of $M$. minimus in Ninh Binh, Ninh Thuan, Ba Ria - Vung Tau, Ho Chi Minh
City, Kien Giang. Kruskop (2013) recorded only on Con Dao Islands. According to Corbet and Hill (1992), this species distributed in south Vietnam, but gave no detailed information. In this study, we recorded $M$. minimus in Kien Giang (U Minh Thuong, Hon Dat) and Ca Mau (Hon Khoai Island). Based on our data of different surveys, and previous publications mentioned above, at least, records of $M$. minimus in northern Vietnam may be misidentification of $M$. sobrinus. Distribution of $M$. minimus in Vietnam based on specimens collected sites were presented in Fig. 5.

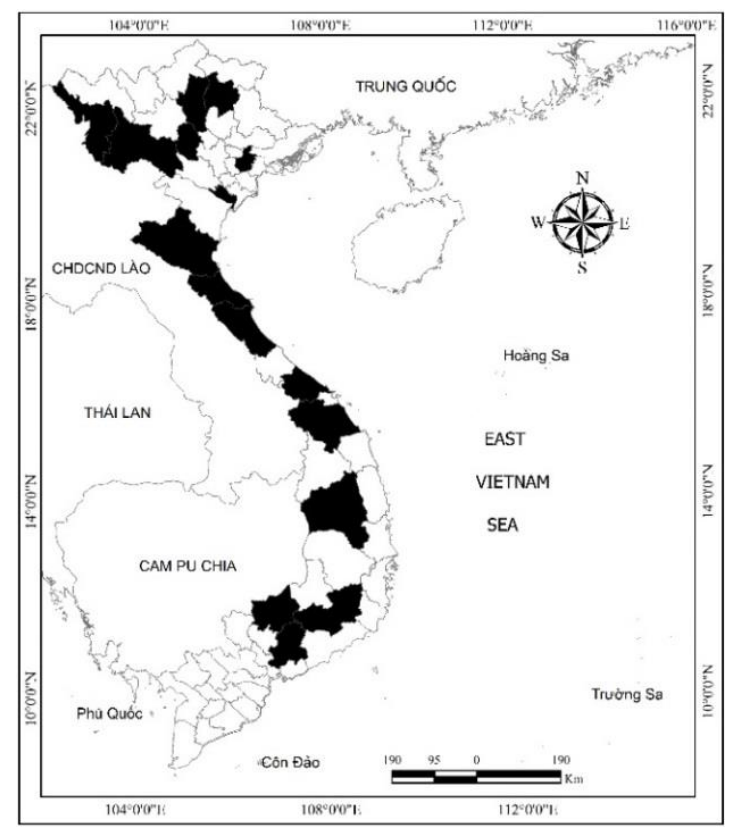

Figure. 4. Distribution of M. sobrinus in Vietnam [ground map was adapted from NARENCA Vietnam, 2010]

Kruskop (2013) recorded a single individual of $M$. minimus from Con Dao National Park, southern Vietnam. We recorded this species with one individual in cajiput wetland, two individuals in an orchard with mangos and bananas, and one individual in Hon Khoai Island. This is the first record of M. minimus in other Island than Con Dao. In total, there may be only five confirmed records of $M$. minimus with detailed information, two from Con Dao Islands (Van 
Peenen et al. 1969, Kruskop 2013) and three from this study (one record from Hon Dat District, one record from $\mathrm{U}$ Minh Thuong National Park, Kien Giang Province; one record from Hon Khoai Island, $\mathrm{Ca} \mathrm{Mau}$ Province). The habits of Long-nosed fruit bats in Vietnam are poorly known. However, natural history of both species are similar (Kruskop, 2013).

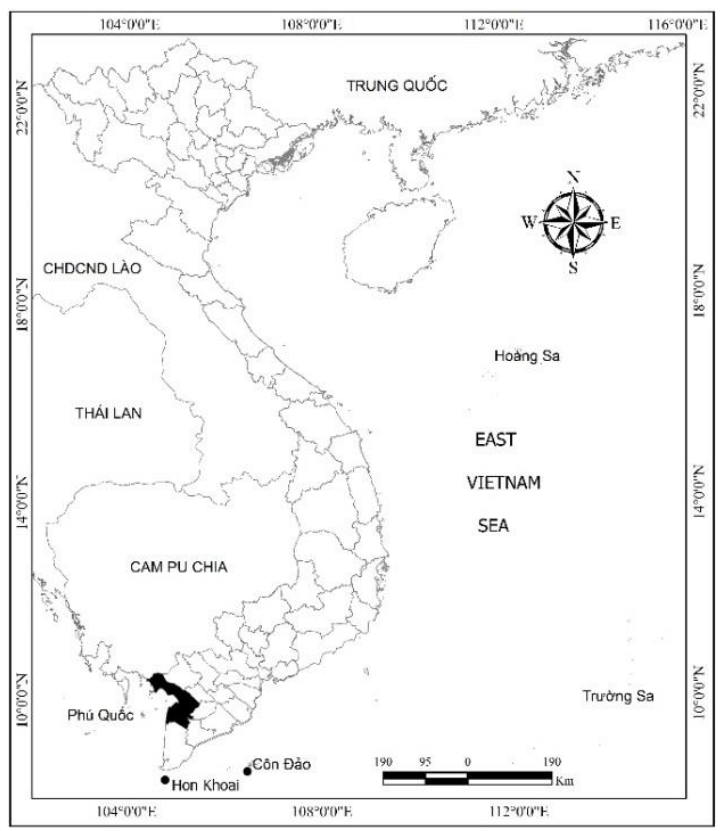

Figure. 5. Current distribution of M. minimus in Vietnam [ground map was adapted from NARENCA Vietnam, 2010]

\section{CONCLUSION}

To date, two species of Long-nosed fruit bats (M. minimus and $M$. sobrinus) are known from Vietnam. They are distinct in all external size, nostril shapes, skull size, rostrum length, tooth row length, and mandible symphyses. Macroglossus sobrinus has been recorded throughout Vietnam whereas $M$. minimus has just been recorded from three localities (Ba Hon, Con Dao, Hon Khoai) in southern region of the country.

Acknowledgements: This research is funded by Vietnam National University, Hanoi in the project code QG 15.19, and the Vietnam National Foundation for Science and
Technology Development (NAFOSTED) under the grants number 106-NN.05-2016.14 and 106.05-2017.35. We thank Mr. Nguyen $\mathrm{Vu}$ Khoi, CEO of Wildlife At Risk (WAR) for the helps and further supports.

\section{REFERENCES}

Andersen K., 1911. Six new fruit-bats of the genera Macroglossus and Syconycteris. Ann. Mag. Nat. Hist., 7(8): 641-643.

Andersen K., 1912. Catalogue of the Chiroptera in the collection of the British Museum, I. Megachiroptera, British Museum (Natural. History), London.

Bates P. J. J., D. L. Harrison, 1997. Bats of the Indian Subcontinent. Harrison Zoological Museum, Sevenoaks, Kent, United Kingdom.

Dang Ngoc Can, Hideki Endo, Nguyen Truong Son, Tatsuo Oshida, Le Xuan Canh, Dang Huy Phuong, Darrin Peter Lunde, Shin-Ichiro Kawada, Akiko Hayashida, Motoki Sasaki, 2008. Checklist of wild mammal species of Vietnam, Shoukadoh Book Sellers, Japan (in Vietnamese).

Chasen F. N., Kloss C.B., 1927. Spolia Mentawiensia - Mammals. With an introduction by C.Boden Kloss. Proc. zool. Soc. Lond. 1927, No. LIII: 797-840.

Corbet G. B., Hill J. E., 1992. The mammals of the Indomalayan region: A systematic review. Oxford University Press, Oxford, United Kingdom.

Cuvier F., 1824. Des dents des mammifères considérées comme caractères zoologiques, p. 248.

Francis C. M., 2008. A field guide to the mammals of South-east Asia. New Holland Publishers Ltd, UK.

Geoffroy E., 1810. Description des rousettes et des cephalotes, deuxnouveaux genres de la famille des chauve-souris. Annls Mus. Hist. Nat. Paris, 15: 86-108.

Hendrichsen D. K., Bates P. J. J., Hayes B. D., Walston J. L., 2001. Recent records of bats (Mammalia: Chiroptera) from 
Vietnam with six species new to the country. Myotis, 39: 35-122.

Hill J. E., 1983. Bats (Mammalia: Chiroptera) from Indo-Australia. Bull. Brit. Mus. nat. Hist. (Zool.), 45: 103-208.

Dang Huy Huynh, Cao Van Sung, Dao Van Tien, Pham Trong Anh, Hoang Minh Khien, 1994. Check list of mammals (Mammalia) of Vietnam. Science and Technics Publishing House, Ha Noi. (in Vietnamese).

Jentink F. A., 1902. Revision of the genera Macroglossus and Syconycteris and description of a new genus and species, Odontonycteris meijeri. Notes from the Leyden Museum Vol. XXIII:131-142.

Le Vu Khoi, Vu Dinh Thong, 2005. Inventory of the bat species (Chiroptera) at the present known in Vietnam. Tap chi Sinh hoc (Journal of Biology), 27(4A): 51-59.

Koopman K., 1994. Chiroptera: Systematics. Handbuch der Zoologie, vol. VIII. Mammalia, part 60, Walter de Gruyter, Berlin.

Kruskop S. V., 2013. Bats of Vietnam: checklist and an identification manual. Joint Russian-Vietnamese Science and Technological Tropical Centre, Moscow, Russia.

Kunz T., Parsons S. (Ed.), 2009. Ecological and Behavioural Methods for the Study of Bats 2nd Edition Edited by Kunz \& Parsons. The John Hopkins University Press.

Lekagul B., McNeely J.A., 1988. Mammals of Thailand. Association for the Conservation of Wildlife, Bangkok, Thailand.

Mickleburgh S.P., A.M. Hutson P.A. Racey, 1992. Old World Fruit Bats. An Action Plan for their Conservation. IUCN/SSC Chiroptera Specialist Group, 252 pp.

Miller G. S., 1907. The families and genera of bats. Bull. U.S. nat. Mus., 57: 1-282.

Morice A., 1875. Coup d'oeil sur la faune de la Cochinchine française. L'Association lyonnaise des amis des sciences naturelles, 14 mars 1875, H. Georg, 101 pp.
Rahman M. R. A., Abdullah M. T., 2010. Morphological Variation in the Dusky Fruit Bat, Penthetor lucasi, in Sarawak, Malaysia. Tropical Natural History, 10(2): 141-158.

Simmons N. B., 2005. Order Chiroptera, in Mammal species of the world: a taxonomic and geographic reference (D. E. Wilson and D. M. Reeder, eds.). 3rd ed, Johns Hopkins University Press, Baltimore, Maryland.

Nguyen Truong Son, Csorba G., 2007. Preliminary results on bat syrvey in Bac Huong Hoa protected area and Dakrong Nature Reserve, Quang Tri province. Proceeding of the $2^{\text {nd }}$ national scientific conference on ecology and biological resources, Ha Noi (in Vietnamese).

Suyanto A., Kitchener D. J., Schmitt L. H., Cooper N. K., 2004. Morphometric variation of island populations of Macroglossus spp. (Chiroptera: Pteropodidae). Treubia, 33(2): 113-135.

Tate G. H. H., 1942. Results of the Archbold Expeditions. No.48. Pteropodidae (Chiroptera) of the Archbold Collections. Bull. Am. Mus. nat. Hist., 80: 331-347.

Hoang Trung Thanh, Nguyen Truong Son, Vu Dinh Thong, Nguyen Vu Khoi, 2015. Bat species composition in Ba Hon Area, Hon Dat district, Kien Giang province. Proceedings of the $6^{\text {th }}$ National Conference on Ecology and Biological Resources, Hanoi: 865-871.

$\mathrm{Vu}$ Dinh Thong, 2002. Results of the bat research at $\mathrm{Pu}$ Hoat area, Nghe An province. Tap chi Sinh hoc (Journal of Biology), 24(2): 15-21.

Van Peenen P. F. D., Ryan P. F., Light R. H., 1969. Prliminary Identification Manual for Mammals of South Vietnam. Smithsonian Institution Press, Washington.

Vietnam Publishing House of Natural, Resources, Environment and Cartographic (NARENCA), 2010. Administrative atlas of Vietnam. 
